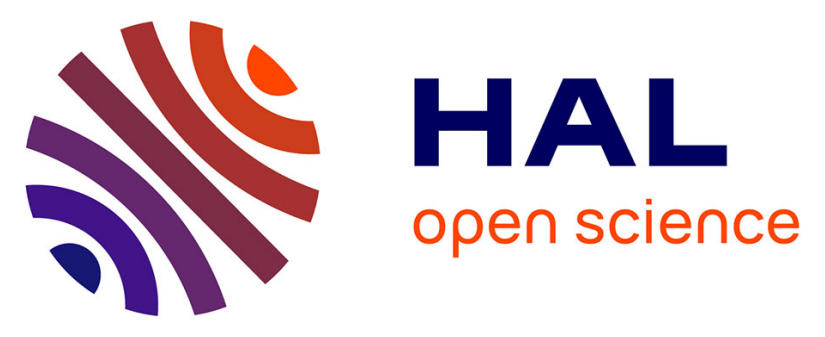

\title{
Organic matter influence on porosity of Kimmeridge-Clay source-rocks: insights from organic petrography and laboratory thermal maturation
} Amélie Cavelan, Mohammed Boussafir, Claude Le Milbeau, Olivier Rozenbaum, Fatima Laggoun-Défarge

\section{To cite this version:}

Amélie Cavelan, Mohammed Boussafir, Claude Le Milbeau, Olivier Rozenbaum, Fatima LaggounDéfarge. Organic matter influence on porosity of Kimmeridge-Clay source-rocks: insights from organic petrography and laboratory thermal maturation. 81st EAGE Conference \& Exhibition, Jun 2019, Londres, United Kingdom. 5 p. insu-02166816

\section{HAL Id: insu-02166816 https://hal-insu.archives-ouvertes.fr/insu-02166816}

Submitted on 27 Jun 2019

HAL is a multi-disciplinary open access archive for the deposit and dissemination of scientific research documents, whether they are published or not. The documents may come from teaching and research institutions in France or abroad, or from public or private research centers.
L'archive ouverte pluridisciplinaire HAL, est destinée au dépôt et à la diffusion de documents scientifiques de niveau recherche, publiés ou non, émanant des établissements d'enseignement et de recherche français ou étrangers, des laboratoires publics ou privés.

\section{(1) (1) $\$$}

Distributed under a Creative Commons Attribution - NonCommercial - NoDerivatives 44.0 
Organic matter influence on porosity of Kimmeridge-Clay source-rocks: insights from organic petrography and laboratory thermal maturation

\title{
Amélie CAVELAN ${ }^{1}$, Mohammed BOUSSAFIR ${ }^{1}$, Claude LE MILBEAU ${ }^{1}$, Olivier ROZENBAUM ${ }^{2}$,
} Fatima LAGGOUN-DEFARGE ${ }^{1}$.

\author{
1 : Université d'Orléans/CNRS/BRGM, Institut des Sciences de la Terre d'Orléans, UMR \\ 7327, 1 A Rue de la Férollerie, 45100 Orléans, France. \\ 2. CNRS-CEMHTI UPR 3079, 1D Avenue de la Recherche Scientifique, 45071 Orléans, \\ Cedex 2 France.
}

\begin{abstract}
This work investigates how slight differences in the relative proportion of OM components and maceral types of marine mudstones throughout a same formation can influence the development and the evolution of OM-pore network during thermal diagenesis of organic-rich marine mudstones. To this end, laboratory gold-tube anhydrous confined thermal maturation, geochemical characterization, organic petrography (palynofacies and macerals analysis), nitrogen adsorption porosimetry, and SEM observations were applied on low-mature marine Kimmeridge Clay (KCF) mudstones. The main properties of organic-rich $\mathrm{KCF}$ samples which exhibit a slightly different total particulate $\mathrm{OM}$ assemblage were compared before and after maturation at $325^{\circ} \mathrm{C}, 390^{\circ} \mathrm{C}$ and $470^{\circ} \mathrm{C}$ for $72 \mathrm{~h}$. The results show that organic-rich KCF samples containing higher proportion of oil-prone orange amorphous organic matter (AOM) derived from phytoplanktonic components have developed smaller pores during thermal maturation resulting in lower pore volumes than samples containing higher proportion of brown AOM derived from the selective preservation of cell-walls of green microalgae. Contrary to brown AOM, orange AOM appears thus to be less favorable to the formation of large mesopores. This result suggests that no clear positive correlation exists between the oil-prone quality (HI) of OM and its ability to develop pores during thermal maturation
\end{abstract}

\section{Introduction}

It has been well documented that thermal maturation of organic matter (OM) with burial is the main factor controlling the development of OM-pores in organic-rich mudstones (Bernard et al., 2012; Katz and Arango, 2018; Ko et al., 2018; Loucks et al., 2012). The available literature reveals that the thermal conversion of kerogen and the subsequent hydrocarbons generation as oil, gas and solid bitumen are closely associated with changes in abundance, shape or size of OM-hosted pores (Bernard et al., 2012; Katz and Arango, 2018; Ko et al., 2018; Loucks et al., 2012). Relationship between maturity and porosity is however, not always clear and contradictions exist between pore evolution models (Katz and Arango, 2018). Previous works suggests that OM-porosity is mainly the result of the secondary cracking of kerogen and bitumen, in response to the exsolution of gas (Bernard et al., 2012). Solid bitumen is thus often considered to be the main contributor to the porosity of thermally-mature mudstones (Bernard et al., 2012). Some evidence shows that OM-hosted pores can be occurred earlier, in the oil window within solid bitumen and/or kerogen (Katz and Arango, 2018; Ko et al., 2018). Furthermore, for a given maturity, two formations containing a type II OM can exhibit very different OM-porosity evolution suggesting that other non-maturity related factors such as the maceral composition may have locally a significant influence on porosity (Katz and Arango, 2018; Ko et al., 2018). For example, Ko et al. (2018) shows that Barnett and Eagle Ford mudstones characterized by differences in Tasmanites abundances exhibit different pore evolution models. Nevertheless, to isolate the influence of these non-maturity related factors on porosity turns out to be a complete exercise (Katz and Arango, 2018). The process of pores development during hydrocarbon generation, the influence of total organic carbon content, and more specifically the influence of the maceral composition needs to be clarified. 
To investigate if the composition of the total particulate OM assemblage influences the development and the evolution of OM-pore network of organic-rich marine mudstones during thermal diagenesis, laboratory gold-tube confined thermal maturation, geochemical characterization, organic petrography (palynofacies and macerals analysis), porosimetry measurement, and SEM observations were applied on low-mature marine Kimmeridge Clay mudstones. The specific research question addressed is the following: do slight differences in the relative proportion of OM components and maceral types of marine mudstones throughout a same formation affect OM pore development and evolution during maturation?

\section{Methods}

Small-diameter rock cylinders and $\approx 1 \mathrm{~g}$ of total rocks powder of immature organic-rich argillaceous marine mudstones collected from the Kimmeridge Clay formation (Ebberston well, Cleveland basin, UK) were artificially matured using anhydrous gold tube confined (600 bars) pyrolysis. The samples were heated under inert-gas and isothermal conditions at temperatures of $325^{\circ} \mathrm{C}, 390^{\circ} \mathrm{C}$ and $470^{\circ} \mathrm{C}$ for 72 hours. Palynofacies analysis was carried out on Kimmeridge Clay mudstones isolated OM (transmitted light microscopy, oil immersion) to quantify the relative proportion of individual organic components before maturation. The small cylinders of immature and artificially matured rocks were impregnated in epoxy resin and argon-ion milled $\left(5 \mathrm{kV}\right.$ for 1 hour, $2 \mathrm{kV}$ for $30 \mathrm{~min}, 4^{\circ}$ tilt angle, 220 $\mu \mathrm{A})$. Petrographic observations were carried under oil immersion using reflected and UV-fluorescence light to identify the different macerals and their evolution with increasing thermal maturity. SEM observations were then conducted using backscatter (BSE) and secondary electron (SE) modes. The amount and the quality of OM before and after maturation were determined using Rock Eval $6^{\circledR}$ pyrolysis. The molecular composition of the gas produced during maturation was determined using a Perkin Elmer® Clarus 580 gas chromatograph fitted with a Supelco® Carboxen 1010 Plot ${ }^{\circledR}$ Capillary column. The total number of moles of gas was quantified assuming ideal gas behavior and using their respective peak areas on chromatograms and calibration curves. About $1 \mathrm{~g}$ of each powdered sample were ultrasonically extracted with a mixture of dichloromethane/methanol $(1 / 1, \mathrm{v} / \mathrm{v})$. The extracts were separated by deactivated silica gel (5\% with water) chromatography column. The aliphatic fractions were recovered by elution with heptane, the aromatic fractions were recovered by the subsequent elution of a mixture of heptane/toluene (3/1) and (1/1). The polar fractions were recovered by elution with methanol. Each fraction was finally dried under nitrogen and weighed to obtain the total extracted mass of saturated, aromatic and polar compounds. The pore volume and the pore-size distribution were measured by nitrogen adsorption measurements using a Quantachrome ${ }^{\circledR}$ NOVA $2200^{\mathrm{e}}$ apparatus. The total pore volume was determined at the relative pressure P/Po of 0.987. To avoid tensile strength effects pore size distributions were determined from the adsorption isotherm using the Barrett, Johner and Halenda (BJH) method (Barrett et al., 1951).

\section{Results and discussion}

The main properties of two representative organic-rich Kimmeridge Clay samples named Sp1 and Sp2 and their evolution with thermal maturity are presented in Figure 1 and 2. These low-mature Kimmeridge Clay mudstones are composed of a well-preserved type II oil-prone kerogen (HI ranges from 418-617 mg HC/g of TOC) mainly composed of brown and orange amorphous organic matter (AOM) derived respectively from cell walls of green microalgae and oil-prone phytoplanktonic OM preserved by natural sulfurization (Figure 1A). These AOM components are supplemented by minor contributions of black AOM and structure organic components $(<18 \%)$ derived from algal spores, phytoplanktonic organic-walled, pollen grains and various debris derived from plant tissues (Figure 1A). In petrographic observations, this is marked by abundant alginite and bituminite macerals (Figure 1B) with a high yellowish to brown UV-fluorescence accompanied by sparse inertinite fragments. In SEM observations, the porosity of all these low-mature rocks is mainly composed of inter-particle mesopores located between grains of calcite, albite and quartz and clay minerals sheets aggregates (Figure 1C). The OM appears gellified and non-porous (Figure 1C) and does not greatly contribute to the total pore volume $(\approx 3.40 \mathrm{cc} / 100 \mathrm{~g}$, Figure $2 \mathrm{~A})$ mainly composed of mesopores in the $2-30 \mathrm{~nm}$ pore size range (Figure $2 \mathrm{~B})$. 
Changes in the OM composition exists between samples (Figure 1A). Sample Sp2 contains higher proportions of oil-prone orange AOM and thus exhibit a slightly higher kerogen quality (HI, Figure 1A) than sample Sp1. In petrographic observations, this is marked by the presence of higher amount of bituminite macerals in $\mathrm{Sp} 2$ (Figure 1B). Conversely, OM of $\mathrm{Sp} 1$ is mainly composed of brown AOM and structured organic components such as plant tissues, algal spores and pollen grains (Figure 1A) with lower amounts of bituminite in petrographic observations.
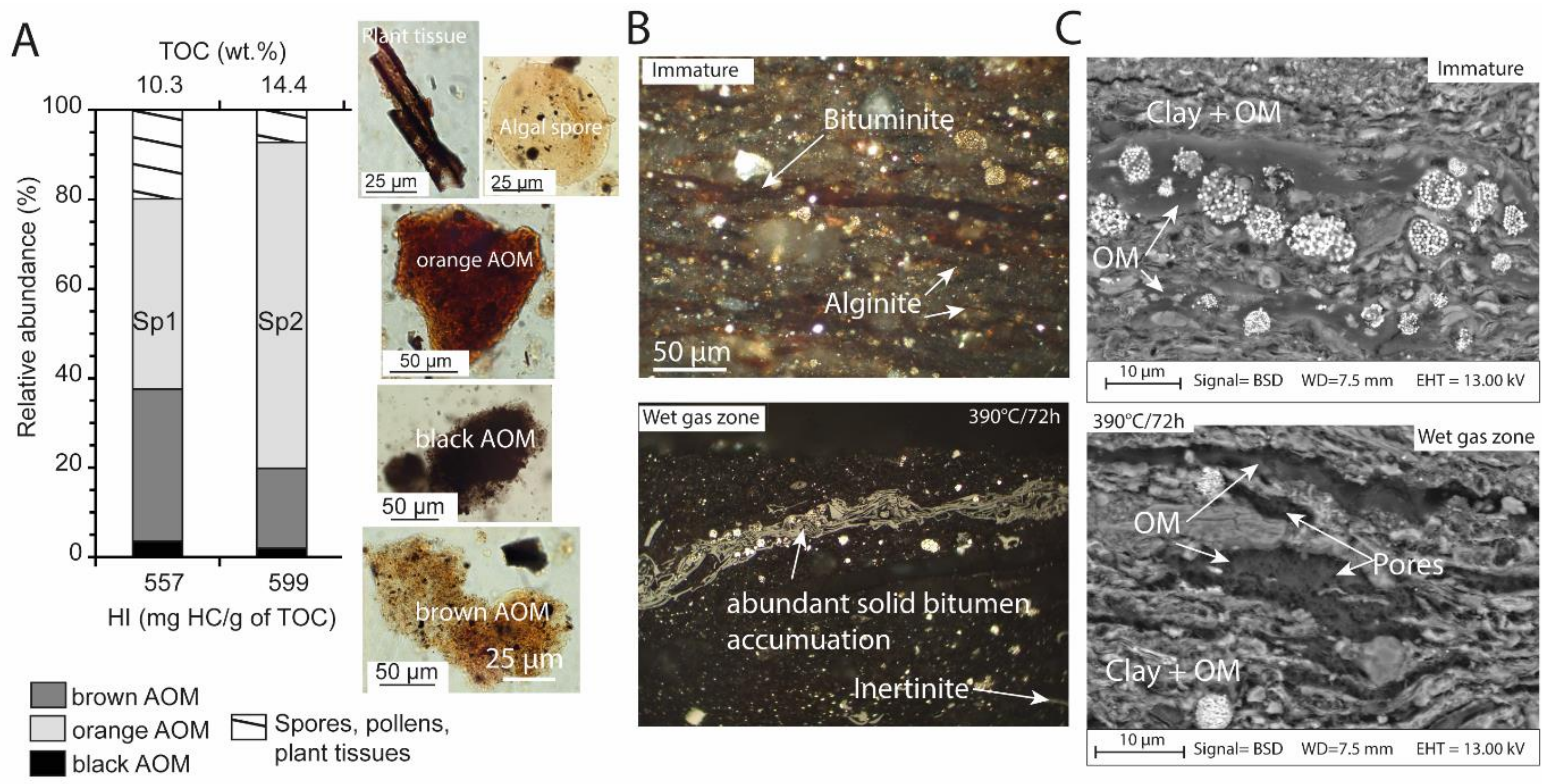

Figure 1 A) Difference of palynofacies composition of 2 low-mature Kimmeridge Clay samples (Sp1 and Sp2) as a function of TOC and hydrogen index (HI). AOM: amorphous organic matter. B) Photomicrographs (oil immersion, transmitted light) and C) SEM images (BSE) of broad ion beam milled thin sections of Kimmeridge Clay samples before and after maturation at $390^{\circ} \mathrm{C} / 72 \mathrm{~h}$. OM: organic matter.

After maturation at $325^{\circ} \mathrm{C} / 72 \mathrm{~h}$, the filling of mesopores by oil and/or bitumen generation and migration appears to have limited the availability of mineral interparticular pores causing the reduction of porosity of all samples. After maturation at $390^{\circ} \mathrm{C}$ and $470^{\circ} \mathrm{C} / 72 \mathrm{~h}$, oil and gas generation (Figure $2 \mathrm{~A}$ ) has occasioned the formation of abundant secondary solid bitumen (Figure 1B) which is the dominant maceral in thermally matured samples. In SEM images, this carbon-rich residue appears to be the main contributor to the porosity of artificially matured Kimmeridge Clay samples (Figure 1C). The formation of these abundant and porous residual macerals is correlated with the re-increase of the pore volume in the gas generation stage (Figure 2A). However, during OM conversion, the difference in the relative proportion of individual OM components between Sp1 and Sp2 has led to changes in the amount of oil and gas generated during thermal maturation (Figure 2A) resulting in a different evolution of pore volume and pore size distribution during the gas generation stage (Figure 2A and B). During OM conversion, the higher proportion of oil-prone orange $\mathrm{AOM}$ of $\mathrm{Sp} 2$ has led to the production of higher amount of low viscous oil, abundant gaseous hydrocarbons and lower $\mathrm{CO}_{2}$ concentrations (Figure 2A) more favorable to the formation of abundant but smaller mesopores than for sample Sp1 (Figure 2B). After maturation at $390^{\circ} \mathrm{C} / 72 \mathrm{~h}$, the porosity of $\mathrm{Sp} 2$ is mainly composed of mesopores smaller than 20 $\mathrm{nm}$ in diameter with a maximum of pores in the $2-7 \mathrm{~nm}$ pore size range (Figure $2 \mathrm{~B}$ ). Meanwhile, the slightly lower oil-potential of Sp1 OM seems to have produced heavier and more viscous oils. The secondary cracking of them have occasioned the formation of greater quantity of non-hydrocarbon gases $\left(\mathrm{CO}_{2}\right.$, Figure $\left.2 \mathrm{~A}\right)$ and abundant secondary solid bitumen more favorable to the formation of fewer but larger mesopores (>10 nm, Figure 2B). 

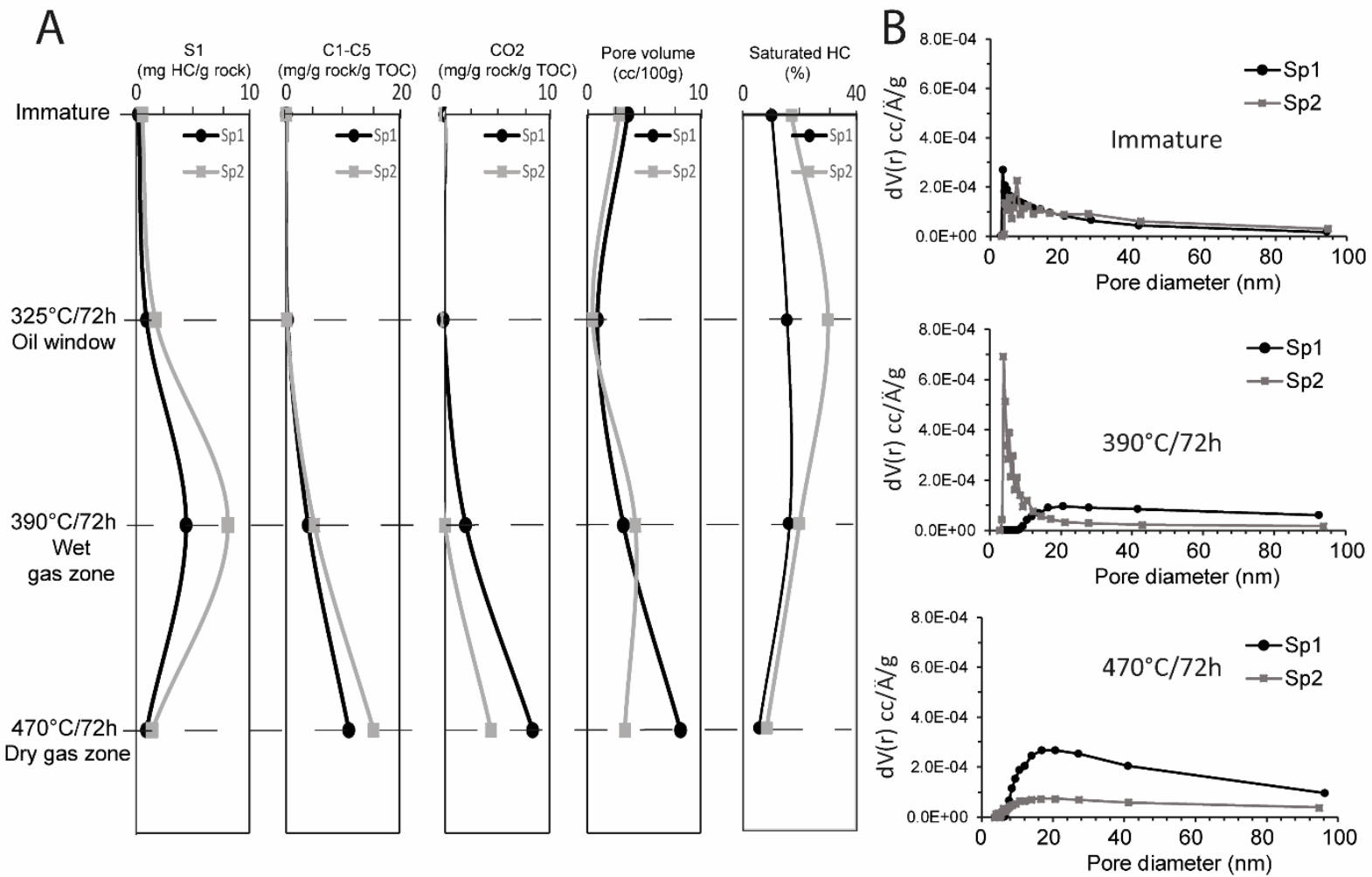

Figure 2 A) Evolution of free hydrocarbons content (S1), condensable gases concentrations (including $\mathrm{CO}_{2}$ and C1-C5: methane, ethane, propane, butane and pentane), pore volume and saturated hydrocarbon content (in percent of the total extractible OM) before and after maturation of two Kimmeridge Clay samples (Spl and Sp2). B) Evolution of the pore size distribution of two Kimmeridge Clay samples (Sp1 and Sp2) before and after maturation at $390^{\circ} \mathrm{C}$ and $470^{\circ} \mathrm{C} / 72 \mathrm{~h}$.

After maturation at $470^{\circ} \mathrm{C} / 72 \mathrm{~h}$, the fine mesopores of $\mathrm{Sp} 2$ have developed and coalesced in response of methane generation to form more complex larger mesopores and macropores (Figure 2B). Surprisingly, this phenomenon has not conduced to the increase of $\mathrm{Sp} 2$ pore volume which remains relatively constant throughout the gas generation stage (Figure 2A and B). Meanwhile, Sp1 OM pore network has also continued to develop in response to the production of methane (Figure 1A). This has led to the strong increase of Sp1 total pore volume (Figure 2B) marked by the formation of abundant mesopores and macropores in the 4-100 $\mathrm{nm}$ pore size range (Figure 2B). Despite a higher oil-prone quality, samples containing higher amount of orange AOM (Sp2) appear thus, to be less favourable to the formation of larges mesopores during thermal maturation resulting in lower pore volume in the dry gas zone (Figure 2A). Samples with the lower oil and gas generation potential are therefore not systematically those who have developed the lower pore volume during maturation. This suggest that the different properties and behaviour of orange and brown AOM during thermal maturation can have a significant influence on OM-pore development and evolution in marine mudstones.

\section{Conclusions}

This work shows that slight variations of the relative proportion of the individual organic components of similar type II kerogen can significantly affect variations of the amount of petroleum and gas generated during maturation and the evolution of porosity throughout a same formation. Our results show that organic-rich KCF samples ( $\mathrm{Sp} 2$ ) containing higher proportion of oil-prone orange AOM preserved by natural sulfurization of phytoplanktonic components exhibit a slightly different pore evolution from samples (Sp1) containing higher proportion of brown AOM derived from the selective preservation of cell-walls of green microalgae. Despite their higher oil-prone quality, samples Sp2 have developed smaller pores during thermal maturation resulting in lower pore volumes. Contrary to brown AOM, orange AOM appears thus to be less favorable to the formation of large mesopores. This suggests that no clear positive correlation exists between the oil-prone quality (HI) of OM and its ability to 
develop pores during thermal maturation. If maturity appears to be the dominant factor controlling porosity, this work shows that non-maturity related factors such as the original oil and gas generation potential tied with the original particulate OM assemblage can be significant. As suggested by previous works, simply considering the level of maturity is thus largely insufficient to understand the development and the evolution of OM pores in organic-rich marine mudstones. That put forward the necessity to clearly identify the composition of the original particulate OM assemblage in order to better predict the amount of oil and gas generated during maturation and the associated porosity development and evolution.

\section{Acknowledgements}

We would like to thank Mrs. Ida Di Carlo for guidance on sample preparation and SEM BSE and SE analysis and Mrs. Rachel Boscardin and Nathalie Lottier for their assistance in the laboratory.

\section{References}

Barrett, E.P., Joyner, L.G., Halenda, P.P., 1951. The Determination of Pore Volume and Area Distributions in Porous Substances. I. Computations from Nitrogen Isotherms. Journal of the American Chemical Society 73, 373-380. https://doi.org/10.1021/ja01145a126

Bernard, S., Wirth, R., Schreiber, A., Schulz, H.-M., Horsfield, B., 2012. Formation of nanoporous pyrobitumen residues during maturation of the Barnett Shale (Fort Worth Basin). International Journal of Coal Geology 103, 3-11. https://doi.org/10.1016/j.coal.2012.04.010

Katz, B.J., Arango, I., 2018. Organic porosity: A geochemist's view of the current state of understanding. Organic Geochemistry 123,16 . https://doi.org/10.1016/j.orggeochem.2018.05.015

Ko, L.T., Ruppel, S.C., Loucks, R.G., Hackley, P.C., Zhang, T., Shao, D., 2018. Pore-types and porenetwork evolution in Upper Devonian-Lower Mississippian Woodford and Mississippian Barnett mudstones: Insights from laboratory thermal maturation and organic petrology. International Journal of Coal Geology 190, 3-28. https://doi.org/10.1016/j.coal.2017.10.001

Loucks, R.G., Reed, R.M., Ruppel, S.C., Hammes, U., 2012. Spectrum of pore types and networks in mudrocks and a descriptive classification for matrix-related mudrock pores. AAPG Bulletin 96, 1071-1098. https://doi.org/10.1306/08171111061 